\title{
Pelacakan Gen Sitokrom Oksidase Subunit 1 (Co1) DNA Mitokondria Pada Itik Tegal (Anas sp.)
}

\author{
Annisa Rizky Rahayu, Hermin Pancasakti dan Anto Budiharjo \\ Laboratorium Biologi Struktur dan Fungsi Hewan, Departemen Biologi, Fakultas Sains dan Matematika, \\ Universitas Diponegoro Jl. Prof. H. Sudharto, Tembalang, Semarang.
}

\begin{abstract}
Itik Tegal adalah salah satu sumber plasma nutfah ternak Indonesia yang belum memiliki informasi asal usul dan identitas genetik, sedangkan ini sangat diperlukan sebagai dasar dalam usaha persilangan dan pemuliaan untuk menghasilkan itik hibrida unggul. Penelitian ini bertujuan untuk mengetahui identitas genetik itik Tegal menggunakan gen sitokrom oksidase subunit 1 (COI) dengan primer BirdF1 dan BirdR1. Penelitian dilakukan dengan cara isolasi DNA dari otot paha itik, diikuti amplifikasi gen CO1, dan sekuensing. Sekuen gen CO1 digunakan untuk analisis hubungan kekerabatan dengan mengkonstruksi pohon filogenetik menggunakan metode neighbor-joining dengan analisis bootstrap 1.000 ulangan. Model Kimura 2-parameter digunakan untuk menghitung jarak genetik dengan pairwise distance. Hasil penelitian memperoleh fragmen gen $\mathrm{CO} 1$ itik Tegal. Fragmen tersebut homolog dengan sekuen gen CO1 Anas platyrhynchos voucher NHMO-BC400. Analisis filogenetik menunjukkan itik Tegal memiliki hubungan kekerabatan paling dekat dengan A. platyrhynchos yang terdistribusi di Skandinavia dan Amerika Utara, A. poecilorhyncha yang terdistribusi di Asia tropis dan timur, serta Tadorna tadorna yang terdistribusi di China.
\end{abstract}

Kata kunci: gen CO1, genetik, itik Tegal

\section{PENDAHULUAN}

Itik (Anas sp.) adalah salah satu jenis unggas yang dikenal oleh masyarakat luas karena menghasilkan produk yang bermanfaat bagi kehidupan manusia. Jenis-jenis itik di Indonesia telah memiliki nama yang disesuaikan dengan nama daerah tempat itik tersebut dikembangbiakkan. Salah satu rumpun itik lokal asli Indonesia yang mempunyai ciri khas dan merupakan kekayaan sumber daya ternak lokal Indonesia adalah itik Tegal. Itik tersebut termasuk bangsa Itik Indian Runner karena memiliki kemampuan untuk menempuh jarak jauh bila digembalakan dari satu tempat ke tempat lainnya (Samosir, 1983; Dinakkeswan Jateng, 2014).

Itik Tegal mempunyai produksi telur tinggi yaitu untuk 100 ekor itik dapat menghasilkan 6070 butir per hari dengan puncak produksi 70,5 $\pm 2,51 \%$ (Kepmentan, 2011; Dinakkeswan Jateng, 2014). Daging itik Tegal merupakan salah satu komoditi unggulan yang digemari oleh masyarakat dengan harga mencapai $\mathrm{Rp}$ 26.000,00/kg (Zulfahmi dkk., 2014). Itik Tegal juga merupakan sumber plasma nutfah ternak yang berguna baik secara ekonomi, ilmu pengetahuan teknologi, dan budaya, baik pada masa kini maupun yang akan datang (Setioko dkk., 2005).

Sampai saat ini belum diketahui ciri-ciri baku masing-masing itik lokal, sedangkan ciri tersebut dibutuhkan dalam pembentukan bangsa itik murni maupun persilangan agar menghasilkan itik hibrida yang unggul (Wulandari dkk., 2005). Upaya pencarian pembeda utama masing-masing itik lokal Indonesia, termasuk itik Tegal biasanya dilakukan berdasarkan struktur morfologi saja. Karakter morfologi seringkali memperlihatkan fenomena species cryptic atau karakter spesies yang samar, sehingga ini bersifat kualitatif, kurang praktis, tidak seragam, dan mudah dipengaruhi subjektivitas (Lahaye et al., 2008).

Persilangan dan pemuliaan itik-itik tersebut membutuhkan teknologi penanda genetik molekuler atau yang dikenal dengan istilah barcode DNA. Menurut Meier et al. (2006), barcode DNAmerupakan sistem identifikasi spesies menggunakan urutan pendek DNA yang dapat dilakukan dalam waktu singkat dan akurat. Salah satu barcode DNA yang sering digunakan adalah gen sitokrom oksidase subunit 1 (COl) (Hebert et al., 2003). Gen CO1 adalah salah satu 
gen dalam DNA mitokondria ( $m t D N A$ ) yang berperan penting dalam produksi energi, sehingga urutan basanya bersifat lestari. Selain itu, mtDNA hewan merupakan genom sitoplasmik yang diwariskan secara uniparental dan tidak mengalami rekombinasi, sehingga spesies yang bersaudara (species sibling) akan memperlihatkan kesamaan tinggi (Syafrina dkk., 2011). Penanda gen $\mathrm{CO} 1$ telah digunakan untuk mengidentifikasi hasil pemuliaan hampir semua hewan baik intraspesies maupun interspesies (Hebert et al., 2003; Ward et al., 2005).

Karakterisasi itik Tegal melalui gen CO1 menjadi diperlukan, karena penggunaan itik tersebut secara luas oleh Dinas Peternakan sebagai induk dalam persilangan dan pemuliaan itik Indonesia. Penelitian ini bertujuan untuk mengetahui identitas genetik itik Tegal berdasarkan hasil pelacakan gen $\mathrm{CO} 1$ dengan menggunakan primer BirdF1 dan BirdR1.

\section{BAHAN DAN METODE Sampel Itik}

Itik Tegal yang digunakan berjumlah dua ekor, berumur tiga bulan, dan berjenis kelamin betina. Itik berasal dari Balai Perbibitan Ternak Unggas Banyubiru Kabupaten Semarang milik Dinas Peternakan dan Kesehatan Hewan Provinsi Jawa Tengah.

\section{Pengamatan Karakteristik Kualitatif dan Kuantitatif}

Itik Tegal diamati karakteristik kualitatifnya, meliputi: warna bulu dominan, bulu kepala, mata, paruh, bulu leher depan, bulu leher belakang, bulu dada, bulu perut, bulu punggung, bulu sayap, bulu ekor, dan kaki. Diamati pula karakteristik kuantitatif itik Tegal, meliputi: lingkar kepala, lingkar leher, lingkar dada, lingkar perut, panjang paruh, panjang leher, panjang tubuh, panjang sayang kanan, panjang sayap kiri, panjang rentang sayap, lingkar paha kanan, lingkar paha kiri, panjang kaki kanan tanpa cakar (shank), panjang kaki kiri tanpa cakar (shank), panjang kaki kanan dengancakar (shank), panjang kaki kiri dengan cakar (shank), dan bobot badan.

\section{Isolasi DNA}

Isolasi DNA diambil dari otot paha itik Tegal. Metode isolasi DNA menggunakan metode fenol-kloroform menurut Ausubel et al. (1995).

\section{Amplifikasi DNA}

Sampel DNA diamplifikasi menggunakan metode menurut Jin et al. (2012).

\section{Elektroforesis Gel Agarosa}

Produk PCR dilakukan running menggunakan elektroforesis horisontal dengan gel agarosa $1 \%$ yang ditambah 81 Goodview dalam bufer TAE 0,5x. Produk PCR ditambahkan loading dye sebelum dimasukkan ke dalam sumuran. Elektroforesis menggunakan marker DNA ladder 100 bp. Hasil elektroforesis diamati dengan UV transilluminator lalu didokumentasikan.

\section{Purifikasi dan Sekuensing}

Produk PCR dipurifikasi dan disekuensing di PT Genetika Science Indonesia lalu digunakan untuk karakterisasi filogenetik.

\section{Analisis Data}

Sekuen gen CO1 dianalisis menggunakan metode BLASTN (BLAST, 2015). Pohon filogenetik dikonstruksi menggunakan metode neighbor-joining dengan analisis bootstrap 1.000 ulangan. Model Kimura 2-parameter digunakan untuk menghitung jarak genetik dengan pairwise distance.

\section{HASIL DAN PEMBAHASAN \\ Hasil Pengamatan Karakteristik Kualitatif dan Kuantitatif}

Itik Tegal yang digunakan dalam penelitian memiliki karakteristik khas. Warna bulu dominan kedua itik adalah cokelat muda dengan totol-totol cokelat tipis, yang merupakan ciri khas itik Tegal lemahan (Gambar 1.). Ini sesuai dengan deskripsi sifat kualitatif dalam keputusan Menteri Pertanian tahun 2011 tentang penetapan rumpun itik Tegal. Warna bulu dominan pada itik Tegal akan terlihat lebih jelas ketika itik dewasa.

Berdasarkan pengamatan karakteristik kualitatif dari kedua itik Tegal (Tabel L.1.) menunjukkan bahwa itik Tegal II memiliki warna 
dan corak bulu yang tampak lebih jelas pada bagian-bagian tubuh tertentu, seperti warna bulu kepala, punggung, sayap, dan ekor. Hal ini dapat dikarenakan laju pertumbuhan bulu itik Tegal II lebih cepat daripada itik Tegal I. Ini ditandai pula dengan masih terdapatnya cukup banyak bulu muda yang berwarna cokelat keputihan pada bagian dada itik Tegal I.
Perbedaan warna bulu itik Tegal I dengan itik Tegal II terutama dipengaruhi oleh faktor genetik masing-masing individu. Warna bulu tubuh, mata, paruh, dan kaki (shank) yang tampak spesifik pada masing-masing itik hampir sepenuhnya dikontrol oleh gen-gen tertentu, sesuai dengan pernyataan Sopiyana dkk. (2006).
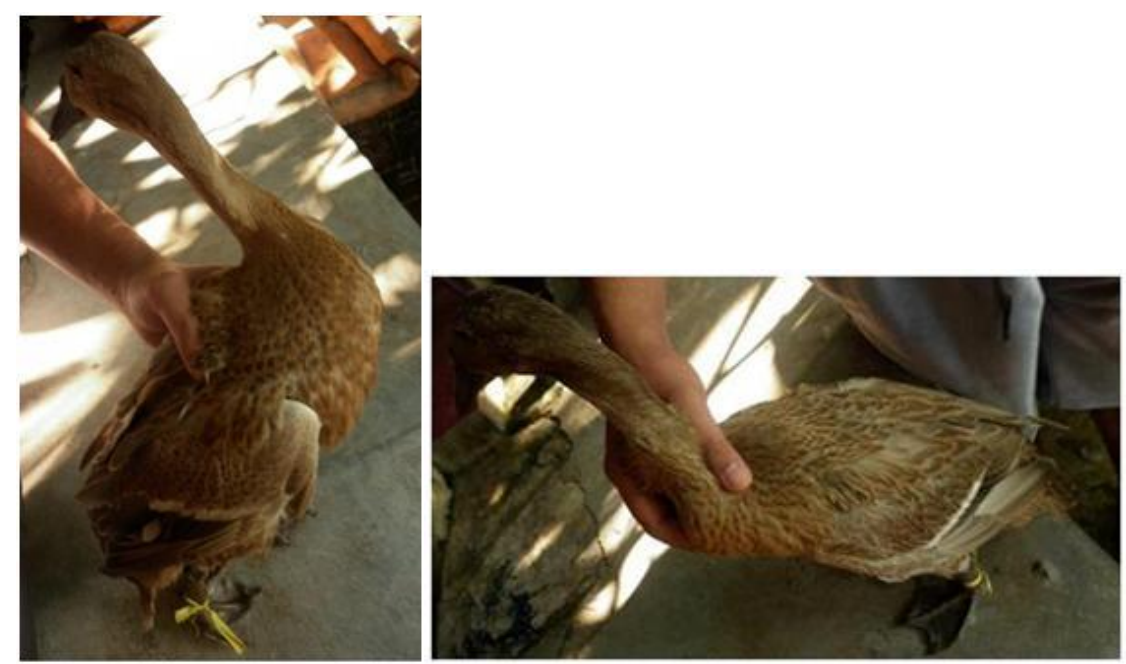

Gambar 1. Itik Tegal I (kiri) dan itik Tegal II (kanan)

Pengamatan karakteristik kuantitatif kedua itik Tegal (Tabel 1.) menunjukkan bahwa itik Tegal II memiliki ukuran tubuh lebih panjang pada bagian-bagian tertentu, seperti lingkar perut, panjang tubuh, panjang sayap, panjang rentang sayap, lingkar paha (kiri), dan panjang kaki dengan cakar (shank). Bobot badan itik Tegal II juga lebih besar daripada itik Tegal I. Namun, ukuran lingkar dada dan panjang leher itik Tegal I lebih panjang.

Tabel 1. Karakteristik kuantitatif itik Tegal I dan II

\begin{tabular}{clccc}
\hline No. & \multicolumn{1}{c}{ Karakteristik Kuantitatif } & \multicolumn{2}{c}{ Ukuran } & Rata-rata \\
\cline { 3 - 4 } & & Itik Tegal I & Itik Tegal II & Ukuran \\
\hline 1. & Lingkar Kepala $(\mathrm{cm})$ & 12,5 & 12,5 & 12,5 \\
\hline 2. & Lingkar Leher $(\mathrm{cm})$ & 7 & 7 & 7 \\
\hline 3. & Lingkar Dada $(\mathrm{cm})$ & 24 & 23,5 & 23,75 \\
\hline 4. & Lingkar Perut $(\mathrm{cm})$ & 26 & 27 & 26,5 \\
\hline 5. & Panjang Paruh $(\mathrm{cm})$ & 6 & 6 & 6 \\
\hline 6. & Panjang Leher $(\mathrm{cm})$ & 55 & 11 & 11,5 \\
\hline 7. & Panjang Tubuh $(\mathrm{cm})$ & 22 & 24,5 & 55,5 \\
\hline 8. & Panjang Sayap Kanan $(\mathrm{cm})$ & 22 & 24 & 23,25 \\
\hline 9. & Panjang Sayap Kiri $(\mathrm{cm})$ & 53 & 57 & 55 \\
\hline 10. & Panjang Rentang Sayap $(\mathrm{cm})$ & 7 & 7 & 7 \\
\hline 11. & Lingkar Paha Kanan $(\mathrm{cm})$ & 6 & 6,5 & 6,25 \\
\hline 12. & Lingkar Paha Kiri $(\mathrm{cm})$ & & & \\
\hline
\end{tabular}




\begin{tabular}{clccc}
\hline 13. & $\begin{array}{l}\text { Panjang Kaki Kanan Tanpa Cakar/ Shank } \\
(\mathrm{cm})\end{array}$ & 6 & 6 & 6 \\
\hline 14. & $\begin{array}{l}\text { Panjang Kaki Kiri Tanpa Cakar/ Shank } \\
(\mathrm{cm})\end{array}$ & 6 & 6 & 6 \\
\hline 15. & $\begin{array}{l}\text { Panjang Kaki Kanan dengan Cakar/ Shank } \\
(\mathrm{cm})\end{array}$ & 14 & 16 & 15 \\
\hline 16. & $\begin{array}{l}\text { Panjang Kaki Kiri dengan Cakar/ Shank } \\
(\mathrm{cm})\end{array}$ & 14 & 16 & 921 \\
\hline 17. & Bobot Badan (g) & 833 & 1009 & \\
\hline
\end{tabular}

Ukuran lingkar perut dan bobot badan itik Tegal II yang lebih besar dimungkinkan dapat berhubungan dengan potensinya dalam memproduksi telur, sedangkan ukuran lingkar dada itik Tegal I yang lebih besar dapat berhubungan dengan potensinya untuk memproduksi daging. Sebagaimana menurut Ismoyowati dkk. (2006), bahwa terdapat korelasi positif antara bobot badan, lingkar perut, dan lebar pubis dengan produksi telur, sedangkan terdapat korelasi negatif antara lingkar dada dengan produksi telur. Ini dikarenakan lingkar dada merupakan salah satu karakteristik yang berhubungan erat dengan produksi daging, sehingga untuk itik tipe petelur mempunyai lingkar dada yang relatif lebih kecil.

\section{Hasil Amplifikasi DNA}

Hasil amplifikasi pada Gambar 2. memperlihatkan terbentuknya 2 pita. Pita pertama berukuran sekitar $700 \mathrm{bp}$, merupakan pita gen target. Ini menunjukkan bahwa primer mampu menempel pada sekuen gen CO1 itik Tegal, sesuai dengan kisaran ukuran produk amplifikasi gen CO1 yaitu 600-800 bp. Pita tersebut terlihat jelas dan tidak smear, tetapi pita yang terbentuk tipis. Hal ini terjadi karena konsentrasi DNA template yang terlalu rendah. Pita kedua yang berukuran sekitar 100 bp juga merupakan produk PCR, tetapi bukan sekuen target. Pita kedua dimungkinkan adalah primerdimer, merupakan sisa primer yang membentuk struktur sekunder karena disebabkan menempelnya sesama primer sejenis ataupun yang tidak sejenis, seperti antara primer forward dengan komplemen primer reverse (Ponchel et al., 2003). Ini dapat terjadi karena konsentrasi primer yang terlalu tinggi.

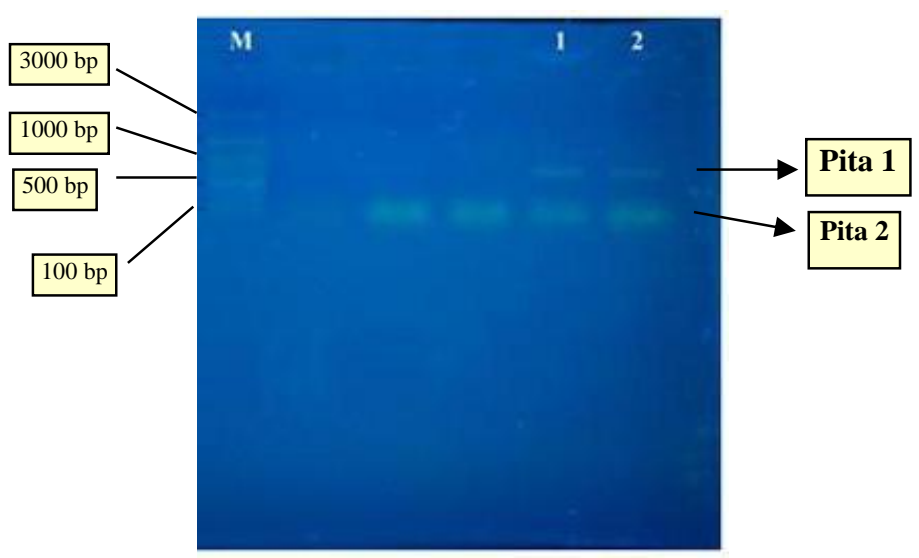

Gambar 2. Hasil amplifikasi DNA itik Tegal; M: marker, 1\&2: fragmen DNA itik Tegal

Pengoptimalan hasil amplifikasi agar lebih spesifik dapat dilakukan dengan mengusahakan beberapa set primer untuk diaplikasikan dalam proses PCR. Apabila diperlukan dapat pula dilakukan perancangan primer tertentu yang spesifik. Optimasi konsentrasi primer juga perlu diperhatikan agar PCR dapat berjalan dengan efisien.

\section{Hasil Sekuensing dan Analisis Gen CO1}

Sekuensing fragmen DNA itik Tegal dari sekuen primer forward dan hasil BLASTN memperoleh sekuen gen CO1 itik Tegal sekitar 700 pb. Hasil BLASTN menampilkan penyejajaran sekuen gen CO1 itik Tegal dengan data serupa yang telah dipublikasikan sebelumnya di GenBank. Penyejajaran bertujuan untuk mencocokkan karakter-karakter homolog dari masing-masing sekuen, yaitu karakter yang mempunyai nenek moyang sama. Nilai dari semua sekuen diwakili oleh garis-garis merah yang menunjukkan bahwa sekuen gen CO1 itik 
Tegal memiliki kemiripan urutan basa dengan data serupa yang ada di GenBank yaitu lebih dari 200 nukleotida.

Hasil penyejajaran sekuen gen CO1 itik Tegal dengan salah satu sekuen menunjukkan bahwa sekuen gen CO1 itik Tegal dengan sekuen gen $\mathrm{CO} 1 \mathrm{~A}$. platyrhynchos voucher NHMO-BC400 memiliki homologi lebih dari 99\% dari 713 basa serta gaps atau nilai kesenjangan mendekati 0\%. Gaps terjadi karena masing-masing sekuen terdapat satu basa yang mengalami delesi dan dua basa yang berbeda urutannya.

Homologi tersebut menunjukkan bahwa keduanya memiliki banyak sekuen basa yang mirip hingga lebih dari 99\%. Sekuen basa tersebut apabila diekspresikan akan menghasilkan struktur dan fungsi protein yang serupa, sehingga kemudian dapat memunculkan kemiripan tertentu.

A. platyrhynchos voucher NHMO-BC400 adalah salah satu spesies burung yang diteliti oleh Johnsen et al. (2010). Spesies ini berkembang biak di Skandinavia dan Amerika Utara, tetapi lebih banyak di Amerika Utara. Habitat pembiakan dari spesies ini yaitu di pedalaman atau di laut.

Warna bulu dominan A. platyrhynchos betina di Skandinavia (Campbell, 2015; Michael, 2015) dan Amerika Utara (Maslowski, 2015) memiliki kemiripan dengan itik Tegal yang digunakan dalam penelitian ini, yaitu cokelat dengan totol-totol cokelat gelap atau kehitaman (untuk yang mulai dewasa). Kemiripan lain adalah pada bagian bulu sayap, yaitu terdapatnya corak putih dan hitam yang dimiliki oleh itik Tegal juga itik di Skandinavia serta Amerika Utara (A. platyrhynchos), meskipun terdapat sedikit warna kebiruan pada itik di Skandinavia serta Amerika Utara.

Walaupun memiliki kemiripan, ternyata terdapat sedikit perbedaan pada warna paruh dan kaki (shank) itik. Pada itik Tegal warna paruh dan kaki dominasi hitam, sedangkan pada itik di Skandinavia serta Amerika Utara terdapat dominasi warna jingga, meskipun terdapat corak hitam pada bagian ujung dan tengah paruh serta selaput kaki kecokelatan. Hal ini dapat dipengaruhi oleh gen-gen tertentu yang spesifik dimiliki masing-masing itik.

\section{Hasil Analisis Hubungan Kekerabatan}

Pohon filogenetik itik Tegal diperlihatkan pada Gambar 3. dengan beberapa spesies yang memiliki kemiripan karakter. Pohon filogenetik tersebut menunjukkan hubungan evolusi antara organisme berdasarkan sekuen gen CO1 masingmasing organisme. Konstruksi metode neighborjoining menghasilkan pohon filogenetik yang dapat mempresentasikan hubungan kekerabatan itik Tegal dengan beberapa spesies atau organisme hingga yang paling dekat, yaitu berdasarkan perbedaan terkecil antara masingmasing sekuen gen $\mathrm{CO} 1$. 


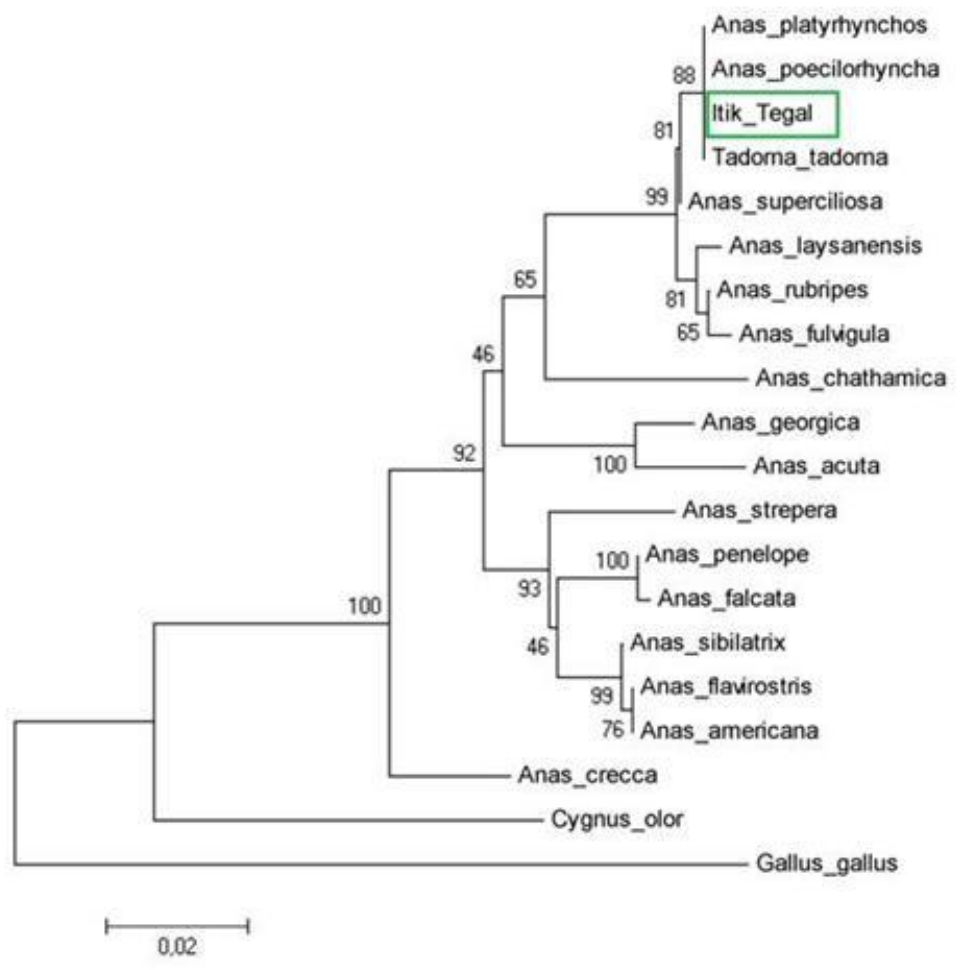

Gambar 3. Pohon filogenetik itik Tegal dan beberapa spesies yang memiliki hubungan kekerabatan berdasarkan sekuen gen $\mathrm{CO} 1$, menggunakan metode neighbor-joining dengan analisis bootstrap 1.000 ulangan dan model Kimura 2-parameter

Pohon filogenetik memperlihatkan itik Tegal berada pada satu klade dengan $A$. platyrhynchos, A. poecilorhyncha, dan Tadorna tadorna, artinya itik Tegal berada pada suatu kelompok taksonomi yang sama dengan ketiga spesies tersebut serta memiliki satu nenek moyang bersama, termasuk semua keturunannya. Ini juga menunjukkan bahwa itik Tegal memiliki hubungan kekerabatan paling dekat dengan A. platyrhynchos, A. poecilorhyncha, dan $T$. tadorna dikarenakan mereka memiliki kemiripan genetik atau tingkat evolusi gen CO1-nya sama. Hal ini diperkuat dengan nilai bootstrap $88 \%$, yang menunjukkan kestabilan pengelompokkan pada pohon filogenetik tersebut. Menurut Campbell \& Reece (2008), suatu takson dianggap setara dengan clade jika takson tersebut monofiletik yaitu terdiri atas spesies nenek moyang dan keturunannya.
Hasil penghitungan jarak genetik (Tabel L.2.) menunjukkan bahwa antara itik Tegal dengan ketiga organisme tersebut tidak terdapat perbedaan genetik atau nilai jarak genetik minimum 0 . Ini berarti antara itik Tegal dengan ketiga organisme tersebut memiliki struktur genetik identik pada lokus gen CO1. Hal ini sesuai dengan pernyataan Finkeldey (2005) bahwa jarak genetik merupakan salah satu parameter yang dapat digunakan untuk mengukur keragaman genetik antar populasi, yaitu dengan mengukur perbedaan struktur genetiknya pada suatu lokus gen tertentu.

Apabila diamati secara fenotip, antara itik Tegal dengan $A$. platyrhynchos dan $A$. poecilorhyncha (Mistry, 2009; Sengupta, 2014) memiliki beberapa persamaan, meskipun terdapat pula beberapa perbedaan yang menjadi ciri khas masing-masing. Persamaan dan perbedaan tersebut diantaranya warna bulu 
dominan itik Tegal memiliki kemiripan dengan A. platyrhynchos di Skandinavia dan Amerika Utara, yaitu cokelat dengan totol-totol cokelat gelap atau kehitaman, tetapi terdapat sedikit warna kebiruan pada bagian sayap itik di Skandinavia serta Amerika Utara. Berbeda dengan A. poecilorhyncha yang memiliki bulu dominan putih keabuan dengan totol-totol hitam kecokelatan serta terdapatnya spekulum kehijauan pada bagian sayap. Untuk paruh dan kaki (shank) itik Tegal berwarna dominasi hitam, sedangkan A. platyrhynchos di Skandinavia dan Amerika Utara dominasi warna jingga dengan corak hitam pada bagian ujung dan tengah paruh serta kecokelatan pada selaput kaki. Berbeda lagi dengan A. poecilorhyncha yang berkembang biak di Asia tropis dan timur, itik ini memiliki warna paruh dominasi hitam dengan bagian depan kuning dan ujungnya hitam serta bagian pangkal paruh terdapat corak jingga yang serupa dengan warna kakinya.

Perbedaan fenotip warna bulu juga terlihat pada T. tadorna (Arco, 2006) yang terdistribusi di China. Itik ini memiliki warna bulu dominan putih dengan bagian kepala hingga leher atas dan sayap luar berwarna hitam mengkilap kehijauan, serta bulu berwarna coklat yang melingkar pada bagian dada bawah, sedangkan paruhnya berwarna merah dan kaki kemerahan. Untuk warna bulu, paruh, dan kaki T. tadorna relatif berbeda dengan itik Tegal, A. platyrhynchos, dan A. poecilorhyncha. Namun, untuk bentuk tubuh dari kepala hingga kaki, keempat itik relatif sama.

Perbedaan-perbedaan yang terdapat pada fenotip warna bulu, paruh, dan kaki keempat itik dapat dipengaruhi oleh tingkah laku itik yang cenderung bermigrasi atau berpindah-pindah untuk mencari makan atau demi mendapatkan daerah aman untuk berkembang biak saat musim kawin. Itik yang berada pada daerah tertentu selama periode waktu tertentu kemudian dapat mengalami perubahan genetis yang dapat berpengaruh pada fenotip atau pun tidak.

Berdasarkan analisis tersebut dapat diketahui bahwa itik yang memiliki fenotip berbeda (seperti warna bulu, paruh, kaki) atau hidup di habitat yang berbeda tidak selalu berarti itik tersebut tidak memiliki hubungan kekerabatan yang dekat, karena fenotip dapat berubah apabila dipengaruhi faktor lingkungan yang berbeda. Selain itu, tidak setiap aspek fenotip selalu diwariskan kepada keturunannya. Berbeda dengan genotip atau struktur genetik yang akan selalu diwariskan ke keturunannya dan memiliki pengaruh yang relatif lebih dominan. Salah satu genotip pada itik adalah sekuens gen CO1, yang dapat dijadikan sebagai dasar dalam menentukan kekerabatan di antara itik, termasuk itik Tegal.

\section{KESIMPULAN}

Pelacakan gen CO1 pada itik Tegal dengan menggunakan primer BirdF1 dan BirdR1 memperoleh fragmen gen $\mathrm{CO} 1$ yang homolog dengan sekuen gen CO1 Anas platyrhynchos voucher NHMO-BC400. Analisis filogenetik menunjukkan Itik Tegal memiliki hubungan kekerabatan paling dekat dengan $A$. platyrhynchos yang terdistribusi di Skandinavia dan Amerika Utara, A. poecilorhyncha yang terdistribusi di Asia tropis dan timur, serta Tadorna tadorna yang terdistribusi di China.

\section{DAFTAR PUSTAKA}

Arco. 2006. Shelduck Female (Tadorna tadorna).

http://www.agefotostock.com/age/en/Stoc k-Images/Rights-Managed/RDCad 134856. 25 Nopember 2015.

Ausubel, F. M., Brent, R., Kingston, R. E., Moore, D. D., Seidman, J. G., Smith, J. A., and Struhl, K. 1995. Short Protocols in Molecular Biology. Third Edition. John Wiley \& Sons, Inc., Canada.

Basic Local Alignment Search Tool. 2015. BLAST. http://blast.ncbi.nlm.nih.gov/Blast.cgi. 31 Desember 2015.

Campbell, L. 2015. Mallard (Anas platyrhynchos).

http://www.arkive.org/mallard/anasplatyrhynchos/image-A6773.html. September 2015.

Campbell, N. A. dan Reece, J. B. 2008. Biologi. Edisi Kedelapan Jilid 2. Alih bahasa: Wulandari, D. T. Erlangga, Jakarta. 
Dinas Peternakan dan Kesehatan Hewan Jawa Tengah. 2014. Itik Tegal. http://www.pertanian.go.id/dinakkeswan_j ateng/play-159-itik-tegal-.html. 13 Desember 2014.

Finkeldey, R. 2005. An Introduction to Tropical Forest Genetics. Institute of Forest Genetics and Forest Tree Breeding GeorgAugust-University-Gottingen, Gottingen.

Hebert, P. D. N., Ratnasingham, S., and de Waard, J. R. 2003. Barcoding Animal Life: Cytochrome C Oxidase Subunit 1 Divergences among Closely Related Species. Proceedings of The Royal Society 270: 96-99.

Ismoyowati, Yuwanta, T., Sidadolog, J. P. H., dan Keman, S. 2006. Hubungan antara Karakteristik Morfologi dan Performans Reproduksi Itik Tegal sebagai Dasar Seleksi. Journal of The Indonesian Tropical Animal Agriculture 31(3): 152156.

Jin, S. D., Hoque, M. R., Seo, D. W., Kim, I. K., Jo, C., Paek, W. K., and Lee, J. H. 2012. Phylogenetic Relationships among Dabbling Duck Species in Korea using COI Gene Variations in mtDNA. Journal of Poultry Science 49(3): 163-170.

Johnsen, A., Rindal, E., Ericson, P. G. P., Zuccon, D., Kerr, K. C. R., Stoeckle, M. Y., and Lifjeld, J. T. 2010. DNA Barcoding of Scandinavian Birds Reveals Divergent Lineages in Trans-Atlantic Species. J. Ornithol. 151: 565-578.

Keputusan Menteri Pertanian. 2011. Keputusan Menteri Pertanian tentang Penetapan Rumpun Itik Tegal. http://bibit.ditjennak.deptan.go.id/upload/d ata/19_-_Itik_Tegal.pdf. 9 Desember 2014.

Lahaye, R., van der Bank, M., Bogarin, D., Warner, J., Pupulin, F., Gigot, G., Maurin, O., Duthoit, S., Barraclough, T. G., and Savolainen, V. 2008. DNA Barcoding The Floras of Biodiversity Hotspots. Proceedings of The National Academy of Sciences 105(8): 2923-2928.

Maslowski, S. 2015. Female Mallard Duck (Anas platyrhynchos), North America.
Note The Webbed Feet. http://www.allposters.com/-sp/FemaleMallard-Duck-Anas-Platyrhynchos-NorthAmerica-Note-the-Webbed-Feet-

Posters_i6011993_htm. 14 September 2015.

Meier, R., Shiyang, K., Vaidya, G., and Peter. 2006. DNA Barcoding and Taxonomy in Diptera: A Tale of High Intraspecific Variability and Low Identification Success. Systematic Biology 55(5): 715728.

Michael, L. 2015. Mallard (Anas platyrhynchos).

http://www.arkive.org/mallard/anasplatyrhynchos/image-A7328.html. September 2015.

Mistry, N. V. 2009. Spot-billed Duck Anas poecilorhyncha poecilorhyncha - Female. http://orientalbirdimages.org/search.php?B ird ID $=183 \&$ Bird Image ID $=40413 \& p=1$ 20. 20 September 2015.

Ponchel, F., Toomes, C., Bransfield, K., Fong, T. L., Douglas, S. H., Field, S. L., Bell, S. M., Combaret, V., Puisieux, A., Mighell, A. J., Robinson, P. A., Inglehearn, C. F., Isaacs, J. D., and Markham, A. F. 2003. Real-Time PCR Based on SYBR-Green I Fluorescence: An Alternative to The TaqMan Assay for A Relative Quantification of Gene Rearrangements, Gene Amplifications and Micro Gene Deletions. BMC Biotechnology 3(18): 113.

Samosir, J. D. 1983. Ilmu Ternak Itik. PT Gramedia, Jakarta.

Sengupta, S. 2014. Spot-billed Duck Anas poecilorhyncha poecilorhyncha - Female. http://orientalbirdimages.org/search.php?B ird_ID $=183 \&$ Bird_Image_ID $=98669 \& \mathrm{p}=2$ 9. 20 September 2015.

Setioko, A. R., Sopiyana, S. dan Sunandar, T. 2005. Identifikasi Sifat-sifat Kualitatif dan Ukuran Tubuh pada Itik Tegal, Itik Cirebon, dan Itik Turi. Seminar Nasional Teknologi Peternakan dan Veteriner 2005.

Sopiyana, S., Setioko, A. R., dan Yusnandar, M. E. 2006. Identifikasi Sifat-sifat Kualitatif dan Ukuran Tubuh pada Itik Tegal, Itik 
Magelang, dan Itik Damiaking. Balai Penelitian Ternak, Bogor.

Syafrina, R. A., Farajallah, A. dan Wardiatno, Y. 2011. Pengembangan DNA Barcode untuk Konservasi Populasi Udang Mantis. Departemen Biologi FMIPA IPB, Bogor.

Ward, R.D., Zemlak, T.S., Innes, B., and Last, P. 2005. DNA Barcoding Australia's Fish Species. Philosophical Transactions of The Royal Society $\quad 360: 1847-1857$.

Wulandari, W. A., Hardjosworo, P. S. dan Gunawan. 2005. Kajian Karakteristik
Biologis Itik Cihateup dari Kabupaten Tasikmalaya dan Garut. Seminar Nasional Teknologi Peternakan dan Veteriner 2005.

Zulfahmi, M., Pramono, Y. B., dan Hintono, A. 2014. Pengaruh Marinasi Ekstrak Kulit Nenas pada Daging Itik Tegal Betina Afkir terhadap Aktivitas Antioksidan dan Kualitas Kimia. Jurnal Aplikasi Teknologi Pangan 3(2): 46-48. 